\title{
ОСОБЛИВОСТІ ІНТЕЛЕКТУАЛЬНОГО РОЗВИТКУ МОЛОДШИХ ШКОЛЯРІВ У ПРОЦЕСІ ВИВЧЕННЯ ОСНОВ ІНФОРМАТИКИ
}

\author{
Шаран О. В. \\ кандидат педагогічних наук, \\ дочент кафедри математики, інформатики \\ та методики їх викладання у початковій школі \\ Дрогобищький державний педагогічний університет імені Івана Франка \\ вул. Івана Франка, 24, Дрогобич, Львівська область, Украӥна \\ orcid.org/0000-0003-3198-8026 \\ Sharan_oleks@ukr.net \\ Шаран В. Л. \\ кандидат фізико-математичних наук, \\ дочент кафедри математики \\ Дрогобицький державний педагогічний університет імені Івана Франка \\ вул. Івана Франка, 24, Дрогобич, Львівська область, Украйна \\ orcid.org/0000-0002-2542-952X \\ Volsharan@ukr.net \\ Пугало С. В. \\ мazicmp \\ Дрогобиџький державний педагогічний університет імені Івана Франка \\ вул. Івана Франка, 24, Дрогобич, Львівська область, Украӥна \\ orcid.org/0000-0003-3921-5335 \\ svetapugalo@gmail.com
}

\author{
Ключові слова: \\ учні початкової школи, \\ інтелект, гармонійний \\ розвиток, основи \\ інформатики, комп'ютер, \\ методика.
}

У статті показано, що формування інтелектуальних здібностей молодшого школяра як невід'ємного складника гармонійного розвитку дитячої особистості є одним із важливих завдань сучасної початкової школи. Відзначається, що інформаційні технології, зокрема й «Сходинки до інформатики» як навчальний предмет, сьогодні посідають чільне місце в процесі інтелектуального розвитку особистості молодшого школяра. Підкреслюється, що якісною характеристикою інтелектуально розвиненого учня $є$ певний рівень сформованості його мислення. Розглядається вплив вивчення інформатики на розвиток мислення учня початкової школи й методичний супровід процесу інтелектуального розвитку молодшого школяра на уроці інформатики. Зокрема, відзначається, що проблемна організація навчання основ інформатики та правильний добір задач сприяють інтелектуальному розвитку учнів. Виділено вимоги до системи задач, що сприяють інтелектуальному розвитку молодших школярів. Розглянуто різні види мислення, які активно можна формуватиза допомогою комп'ютерів, а саме: операційне, алгоритмічне, логічне і творче мислення. Наведено приклади прикладного програмного забезпечення, що спрямовані на розвиток інтелекту й адаптовані для навчання дітей молодшого шкільного віку. Підкреслено важливу роль створення тренінгового ігрового середовища та вказано види найбільш доцільних програмних ресурсів. Відзначено також важливість використання інтерактивних завдань і робітпроєктів. Виділено типи ігрових програм, що сприяють інтелектуальному 
розвитку молодших школярів і які доцільно використовувати на уроках інформатики в початковій школі: закриті, відкриті й дослідницькі. Відзначено також позитивну роль комфортної психологічної атмосфери на уроці інформатики в початковій школі. Зроблено висновок, що інтеграція комп'ютера в освітній процес, його органічне поєднання 3 традиційними методами навчання з дотриманням виділених дидактичних умов позитивно впливають на розвиток інтелекту молодшого школяра.

\title{
PECULIARITIES OF INTELLECTUAL DEVELOPMENT OF JUNIOR SCHOOLCHILDREN IN THE PROCESS OF STUDYING THE FUNDAMENTALS OF INFORMATICS
}

\author{
Sharan O. V. \\ Candidate of Pedagogical Sciences, \\ Associate Professor at the Department of Mathematics, Informatics and Methods of Teaching at \\ Elementary Scools \\ Drohobych Ivan Franko State Pedagogical University \\ Ivan Franko str., 24, Drohobych, Lviv region, Ukraine \\ orcid.org/0000-0003-3198-8026 \\ Sharan_oleks@ukr.net
}

\author{
Sharan V. L. \\ Candidate of Physical and Mathematical Sciences, \\ Associate Professor at the Department of Mathematics \\ Drohobych Ivan Franko State Pedagogical University \\ Ivan Franko str., 24, Drohobych, Lviv region, Ukraine \\ orcid.org/0000-0002-2542-952X \\ Volsharan@ukr.net \\ Pugalo S. V. \\ Master \\ Drohobych Ivan Franko State Pedagogical University \\ Ivan Franko str., 24, Drohobych, Lviv region, Ukraine \\ orcid.org/0000-0003-3921-5335 \\ svetapugalo@gmail.com
}

Key words:

elementary school pupils, intelligence, harmonious development, basics of informatics, computer, method.
The article shows that the formation of the intellectual abilities of elementary school children as an integral part of the harmonious development of children's personality is one of important tasks of modern elementary school. It is highlighted that information technology, and hence the "Steps to Informatics" as a subject, today occupy a prominent place in the intellectual development of the junior pupil's personality. It is emphasized that the qualitative characteristic of an intellectually developed pupil is a certain level of his thinking formation. The influence of studying informatics on elementary school pupil's thinking development and methodical support of the process of his intellectual development on informatics lessons are considered. In particular, it is noted that the problematic organization of teaching the basics of informatics and the correct choice of tasks contribute to pupils' intellectual development. Requirements to the system of tasks that promote the intellectual development of junior schoolchildren are allocated. Various types of thinking 
that can be actively formed with the help of computers are considered, in particular: operational, algorithmic, logical, and creative thinking. Examples of software applications focused on intelligence development and adapted for the education of elementary school children are given. The importance of creating a training game environment is emphasized. The types of the most appropriate software resources are indicated. The importance of using interactive and project tasks is also noted. The closed, open, and research types of game programs are highlighted as they promote the intellectual development of elementary school children and should be used in informatics lessons in elementary school. The positive role of a comfortable psychological atmosphere in informatics lessons in elementary school is also noted. It is concluded that the integration of computers into the educational process and its organic combination with traditional teaching methods in compliance with the selected didactic conditions have a positive impact on the development of elementary school children's intelligence.

Постановка проблеми. Важливим завданням загальної початкової освіти є формування інтелектуальних здібностей молодшого школяра як невід'ємного складника гармонійного розвитку дитячої особистості. На сучасному етапі розвитку суспільства існує потреба у творчих, ініціативних, інтелектуально й духовно розвинутих громадянах. Як відомо, фундамент особистості формується у віці до 11-13 років. Початкова школа повинна брати активну участь у цьому процесі. Потужними можливостями в розв'язанні окресленої проблеми володіють «Сходинки до інформатики» як навчальний предмет у початковій ланці освіти.

Поняття «інтелект», «інтелектуальний розвиток», «розумовий розвиток» розглядалися вченими з різних галузей знань, зокрема психологами (Б. Ананьєвим, Д. Богоявленським, Д. Ельконіним, А. Занковим, К. Кабановою-Меллер, Н. Лейтесом, К. Менчинською, С. Рубінштейном та ін.) і педагогами (Т. Жижко, В. Крутецьким, О. Чашечниковою та ін.).

Метою статті $\epsilon$ визначення дидактичних умов інтелектуального розвитку молодших школярів у процесі вивчення основ інформатики.

Виклад основного матеріалу. Під інтелектом розуміємо (за С. Гончаренком) «розумові здібності людини: здатність орієнтуватися в навколишньому середовищі, адекватно його відображати й перетворювати, мислити, навчатися, пізнавати світ і переймати соціальний досвід; спроможність розв'язувати завдання, приймати рішення, розумно діяти, передбачати. Структура інтелекту включає такі психічні процеси, як сприймання й запам'ятовування, мислення й мовлення тощо» [1, c. 146-147].

Основними цінностями сучасного суспільства стають не матеріальні цінності, а інформація та наукові знання, інтелект. Змінюються методи й засоби навчання школярів; перевага надається в основному інформаційно-комунікаційним, у тому числі дистанційним, засобам. Отже, інформаційні технології сьогодні посідають чільне місце в процесі інтелектуального розвитку особистості учня й, зокрема, молодшого школяра.

Уважаємо, що якісною характеристикою інтелектуально розвиненого учня $\epsilon$ певний рівень сформованості його мислення. «Грунтовне опанування знаннями змістово й функціонально пов'язане 3 розвитком стилю мислення. ..» [2, с. 87]. Відомо, що мислення людини розпочинається 3 поставленого перед нею завдання, активного сприйняття його умови та чіткої спрямованості на його розв'язання.

Важливим етапом у пошуках впливів навчання, які б сприяли розвитку людського інтелекту, $\epsilon$ звернення вчених-дослідників і педагогів-практиків до проблемного навчання [3, с. 31].

Уважаємо, що проблемне навчання основ інформатики і правильний добір задач сприяють інтелектуальному розвитку учнів. Така система задач повинна:

1) сприяти створенню розвивального середовища для учня;

2) забезпечувати зростання рівня складності, що передбачає самостійну постановку й реалізацію задумів у процесі розв' язування задачі;

3) задачі повинні бути узгоджені з тим матеріалом, який вивчається згідно 3 програмою початкової школи, і бути доступними для розуміння дитиною;

4) система задач повинна здійснювати пропедевтичну функцію у вивченні інформатики в основній школі.

За допомогою комп'ютерів активно можна формувати різні види мислення. Основним із них $\epsilon$ операційний стиль мислення, що включає вміння аналізувати умову задачі, формалізувати іiі; виділити в ній логічно самостійні частини; визначити взаємозв'язок цих частин; спроектувати рішення за допомогою різних програмних засобів; верифікувати результат. 
Модель процесу розв'язування задачі досить часто має алгоритмічний характер, що сприяє формуванню алгоритмічного, логічного мислення, освоєння основ програмування.

Одним із ефективних засобів розвитку інтелекту молодших школярів $є$ «грамотне використання вчителем комп'ютерних навчальних програм, які дають змогу організувати самостійну діяльність учнів 3 набуття знань і їх постійного поглиблення. Такі засоби навчання володіють зовнішньою цікавістю, яка може трансформуватися у внутрішній мотив...» [4, с. 101].

Програмних засобів, адаптованих для навчання дітей молодшого шкільного віку, натепер існує досить багато. Пакети програмного забезпечення містять велику кількість різноманітних програм - від програм-тренажерів, програм дидактичного характеру для опанування різними навчальними предметами до ігор і головоломок, а також візуальних середовищ програмування. Тому ці пакети можуть бути використані під час вивчення багатьох тем предмета, під час роботи над навчальними проєктами, на уроках повторення, узагальнення й систематизації навчального матеріалу. Наприклад, комплект GCompris, офісний пакет OOo4Kids, комплекти «Світ Інформатики. 1-2 рік навчання» та «Світ інформатики. 3-4 рік навчання», візуальне об'єктно орієнтоване середовище програмування Scratch, програма «Комп'ютерна азбука», візуальне середовище для створення ігор без програмування Kodu й багато інших.

Уважаємо, що в процесі гармонійного розвитку дитини молодшого шкільного віку розвиток інтелекту є невіддільним від розвитку ії творчих здібностей. Виникає необхідність створення відповідного тренінгового середовища. Одним iз принципових моментів створення інтелектуально-творчого тренінгового середовища $є$ використання ігор. Метою використання інтелектуально-творчих комп'ютерних ігор $\epsilon$ розвиток інтелектуально-творчого потенціалу учнів, опанування ними прийомами і стратегіями інтелектуальної й творчої діяльності через утілення своїх задумів за допомогою вибору найбільш доцільних програмних ресурсів. Це можуть бути комп’ютері ігри-кросворди, комп'ютерні енциклопедії, подорожі, комп'ютерні топологічні схеми, комп'ютерні підручники з ілюстраціями й завданнями в ігровій формі, комп'ютерні обчислювальні ігрові й алгоритмічні середовища, комп'ютерні середовища управління виконавцями.

Відомо, що учні початкової школи з великим інтересом сприймають навколишню дійсність [5]. Однак їхнє сприйняття, особливо на початку молодшого шкільного віку, тісно пов'язане 3 практичною діяльністю дитини. Тому навчальний матеріал у процесі вивчення основ інформатики доцільно подавати також в інтерактивних завданнях, виконуючи які діти отримують нові знання. Наприклад, пізнавальною $є$ інтерактивна вправа «Вир» для сортування об'єктів, завдання на встановлення відповідності, на множинний вибір, на впорядкування зображень, понять за певним критерієм тощо.

Ще однією 3 форм організації інтелектуально-творчого середовища для молодших школярів $\epsilon$ роботи-проєкти. Таку форму роботи доцільно використати 3 тих тем, які можна інтегрувати 3 іншими навчальними предметами. При цьому пізнавальна діяльність учнів під впливом міжпредметних зв'язків і дослідницької форми роботи значно активізується. Наприклад, можна запропонувати виконати завдання-проєкт на складання кросворду 3 певної теми в процесі освоєння учнями текстового та графічного редактора, створення газети, журналу, веб-сторінки тощо. Доступним для молодших школярів $є$ оформлення знайдених матеріалів у вигляді презентації, наприклад, під час виконання проєктів «Лікарські рослини», «Вітаміни в нашому житті», «Мистецька галерея» тощо. Крім цього, можна використовувати додаткові ефекти, такі як музичний супровід, запис голосового супроводу, оформлення з додаванням анімації, вставки діаграм, рисунків тощо. Цікавими також дітям $є$ проєктні роботи в середовищі програмування Scratch тощо.

Отже, на уроках інформатики в початковій школі доцільна робота 3 ігровими програмами різного типу:

- закритими, де розв'язуються дидактичні завдання, що становлять основу інтелекту;

- відкритими, які призначені для розвитку інтелекту, фантазії, творчості;

- дослідницькими, що допускають експериментування.

Зазначені види ігрових програм сприяють інтелектуальному розвитку молодших школярів. Проте мета використання ігрових програм повинна відповідати цілям загальноосвітнього курсу інформатики, а самі програми мають підтримувати змістово-методичні лінії навчальної дисципліни.

Відзначимо, що комфортна психологічна атмосфера на уроці інформатики в початковій школі, що включає похвалу вчителя за правильно виконане завдання, підбадьорення в разі невдачі та заохочення до подальшого виконання завдань, а також виховання наполегливості, співпереживання героям, бажання допомогти й переборювати труднощі, планування, контроль та оцінювання результатів самостійної діяльності, $є$ позитивним чинником у розвитку інтелекту дітей молодшого шкільного віку. 
Висновки. Ураховуючи все сказане вище та досвід упровадження результатів дослідження в практику роботи початкової школи, можемо зробити висновок, що інтеграція комп'ютера в освітній процес, його органічне поєднання 3 традиційними методами навчання 3 дотриман- ням виділених дидактичних умов позитивно впливають на розвиток інтелекту молодшого школяра. Перспективи подальших розробок убачаємо в дослідженні впливу інших навчальних предметів на інтелектуальний розвиток молодших школярів.

\section{Література}

1. Гончаренко С. Український педагогічний словник. Київ : Либідь, 1997. 375 с.

2. Шаран О.В. Особливості інтелектуального розвитку молодших школярів на уроках математики та шляхи формування їх зацікавленості до навчання. Молодь і ринок. 2012. № 11 (94). С. 87-89.

3. Жижко Т. Місце і роль проблемного навчання в інтелектуальному розвитку особистості. Вісник Черкаського університету. Серія «Педагогічні науки». 2002. Вип. 35. С. 28-33.

4. Шаран О.В., Левак Г.Р. Особливості формування пізнавального інтересу учнів початкової школи у процесі вивчення основ інформатики. Психологія та педагогіка: сучасні методики та інновації, досвід практичного застосування : збірник тез наук. робіт Міжнар. наук.-практ. конф., м. Львів, 25-26 жовт. 2019 р. Львів, 2019. Ч. 2. С. 99-102.

5. Крутецкий В.А. Психология обучения и воспитания школьников: книга для учителей и классных руководителей. Москва : Просвещение, 1976. 303 с.

\section{References}

1. Honcharenko C. (1997). Ukrainskyi pedahohichnyi slovnyk. [Ukrainian pedagogical dictionary]. Kyiv : Lybid. 375 p. [in Ukrainian].

2. Sharan O. V. (2012). Osoblyvosti intelektualnoho rozvytku molodshykh shkoliariv na urokakh matematyky ta shliakhy formuvannia yikh zatsikavlenosti do navchannia. [Features of intellectual development of junior schoolchildren in mathematics lessons and ways of forming their interest in learning]. Molod $i$ rynok. № 11 (94). Pp. 87-89 [in Ukrainian].

3. Zhyzhko T. (2002). Mistse i rol problemnoho navchannia v intelektualnomu rozvytku osobystosti. [The place and role of problem-based learning in the intellectual development of the individual]. Visnyk Cherkaskoho universytetu. Ser.: Pedahohichni nauky. Vol. 35. Pp. 28-33 [in Ukrainian].

4. Sharan O. V., Levak H. R. (2019). Osoblyvosti formuvannia piznavalnoho interesu uchniv pochatkovoi shkoly u protsesi vyvchennia osnov informatyky. [Features of formation of cognitive interest of elementary school pupils in the process of studying the fundamentals of informatics]. Psykholohiia ta pedahohika: suchasni metodyky ta innovatsii, dosvid praktychnoho zastosuvannia : zb. tez nauk. robit mizhnar. nauk.-prakt. konf. Lviv. Vol. 2. Pp. 99-102 [in Ukrainian].

5. Kruteckij V. A. (1976). Psihologija obuchenija i vospitanija shkol'nikov: kniga dlja uchitelej i klassnyh rukovoditelej. [Psychology of teaching and education of schoolchildren: a book for teachers and class teachers]. Moskva : Prosveshhenie. 303 p. [in Russian]. 